\title{
PENGENDALIAN PROYEK DENGAN EARNED VALUE METHOD (EVM) PADA PROYEK PEMELIHARAAN JALAN PROVINSI DENPASAR- SIMPANG PESANGGARAN
}

\author{
Ida Ayu Putu Sri Mahapatni ${ }^{1}$,Ida Bagus Wirahaji ${ }^{2}$, I Made Harta Wijaya ${ }^{3}$ \\ ${ }^{1,2,3}$ Program Studi Teknik Sipil Universitas Hindu Indonesia \\ Email: (dayumaha71@yahoo.com²,ib.wirahaji@gmail.com²,cokguang@gmail.com)
}

\begin{abstract}
ABSTRAK
Pengendalian Proyek Pemeliharaan Jalan Provinsi Denpasar-Simpang Pesanggaran dengan menggunakan metode Earned Value.Tujuan penelitian adalah untuk mengetahui varian biaya dan jadwal (Cost Variance/CV dan Schedule Variance/SV), untuk mengetahui indeks kinerja dari segi biaya dan waktu (Cost Performance Index/CPI dan Schedule Performance Index/SPI) dan untuk mengetahui perkiraan biaya dan waktu untuk penyelesaian proyek. Jenis penelitian ini adalah deskriptif kuantitatif. Hasil dari penelitian ini adalah kinerja proyek pada minggu pertama menghasilkan CV positif, SV negatif, SPI $<1$ dan CPI $>1$, berarti pekerjaan lebih lambat dari jadwal dengan biaya yang lebih kecil dari yang dianggarkan. Pada minggu kedua, ketiga dan keenam menghasilkan CV negatif, SV negatif, SPI $<1$ dan $\mathrm{CPI}<1$, berarti terjadi keterlambatan dan pembengkakan biaya. Pada minggu keempat dan kelima menghasilkan CV negatif, SV positif, SPI $>1$ dan $\mathrm{CPI}<1$, berarti pekerjaan lebih cepat dari jadwal dengan biaya yang lebih besar dari yang dianggarkan. Pada minggu ketujuh sampai dengan minggu duapuluh menghasilkan $\mathrm{CV}$ positif, SV positif, SPI $>1$ dan $\mathrm{CPI}>1$, pekerjaan lebih cepat dari jadwal dengan biaya yang lebih kecil dari yang dianggarkan. Hal ini berarti Proyek Pemeliharaan Berkala Jalan Provinsi DenpasarPesanggaran, setelah dianalisis dengan Earned Value Method, perkiraan biaya total dan waktu penyelesaian proyek tidak mengalami kerugian dan tidak mengalami keterlambatan.
\end{abstract}

Kata kunci: $E V, C V, S V, C P I$ dan $S P I$

\section{PENDAHULUAN}

Proyek konstruksi memiliki karakteristik unik yang tidak berulang. Proses yang terjadi pada suatu proyek tidak akan berulang pada proyek lainnya. Hal ini disebabkan oleh kondisi yang mempengaruhi proses suatu proyek konstruksi berbeda satu sama lain. Pengendalian (kontrol) diperlukan untuk menjaga kesesuaian antara perencanaan dan pelaksanaan. Tiap pekerjaan yang dilaksanakan harus benar-benar diinspeksi dan dicek oleh pengawas lapangan, apakah sudah sesuai dengan spesifikasi atau belum. Pengendalian merupakan proses membandingkan apa yang terjadi dengan apa yang seharusnya terjadi. Pengendalian tidak akan bisa dilakukan jika kegiatan pekerjaan belum dimulai, dan kegiatan tidak dimulai tanpa perencanaan. Pelaksanaan pekerjaan tanpa perencanaan kurang mendapatkan hasil yang diinginkan bahkan merugikan. Jika hasil analisis pengendalian pekerjaan tidak memenuhi standar, perubahanperubahan atas perencanaan ulang akan terjadi pada pekerjaan selanjutnya. Dengan demikian, perencanaan dan pengendalian adalah proses yang terus menerus berulang dilakukan dan merupakan hal yang tidak terpisahkan sampai proyek diselesaikan. Berbagai metode dapat diterapkan dalam melakukan pengendalian proyek, sehingga dapat mengungkap terjadinya penyimpangan dengan cepat dan akurat. (Ervianto, 2004)

Biaya dalam anggaran berjalan ditetapkan secara periode demi periode untuk setiap paket kerja atau rekening biaya tertentu. Setelah proyek berjalan sampai waktu tertentu perlu dilihat perkembangan pekerjaan untuk paket kerja tersebut serta biaya yang dikeluarkan dan dibandingkan dengan biaya yang dianggarkan setiap periode tertentu. Pengukuran kemajuan kerja didasarkan pada apa yang dimaksud earned value.(Santosa, 2008).Menganalisis pengendalian waktu dan biaya dengan metode EV dilakukan pada Proyek Pemeliharaan Berkala Jalan Provinsi Denpasar-Pesanggaran dengan menggunakan data-data perencanaan yang berdasarkan kontrak, seperti Rencana Anggaran Biaya, analisa harga satuan, dan time 
schedule. Kontraktor pelaksananya adalah PT Aditya Sinar Pratama, sedangkan Konsultan Pengawasnya adalah CV Veygasi Disain KSO CV Artha Pratama. Besar nilai proyek berdasarkan Rencana Anggaran Biaya (RAB) adalah Rp 16.169.998.000 ( Enam Belas Milyar Seratus Enam Puluh Sembilan Juta Sembilan Ratus Sembilan Puluh Delapan Ribu Rupiah). Rencana penyelesaian proyek adalah 180 hari atau sampai minggu ke 26. Berdasarkan Permen PU 13 tahun 2011 proyek pemeliharaan berkala jalan adalah kegiatan penanganan yang lebih luas dan setiap kerusakan yang diperhitungkan dalam desain agar penurunan kondisi jalan dapat dikembalikan pada kondisi kemantapan sesuai rencana. Adapun bagianbagian konstruksi yang perlu dipelihara adalah struktur perkerasan jalan, bahu jalan, fasilitas pejalan kaki/trotoar, fasilitas drainase, perlengkapan jalan, lereng/talud jalan dan struktur pendukung lain. Berdasarkan data lapangan proyek tersebut mengalami banyak masalah yang tidak sesuai antara pelaksanaan dengan perencanaan, seperti adanya banyak pohon besar yang menghalangi pekerjaan trotoar, adanya kurang lebih 50 lobang dari pekerjaan DSDP yang sangat mempengaruhi kinerja pengaspalan, adanya perbaikan pipa yang dilakukan oleh PDAM karena terjadi kebocoran pipa, sehingga pada proyek tersebut terjadi banjir dan jalan menjadi macet akibatnya pekerjaan trotoar dan pengaspalan menjadi terhambat, adanya keterlambatan pengiriman material dan banyaknya pekerja libur lebih awal tidak sesuai dengan time schedule yang telah direncanakan. Masalahmasalah yang terjadi pada saat mulai pekerjaan maka diperlukan pengendalian proyek dengan menganalisis proyek perminggu, sehingga lebih cepat mengontrol biaya dan waktu supaya sesuai dengan perencanaan dengan menggunakan Earned Value Method. Tujuan penelitian ini adalah untuk mengetahui varian biaya dan jadwal (Cost Variance/CV dan Schedule Variance/SV), untuk mengetahui indeks kinerja dari segi biaya dan waktu (Cost Performance Index/CPI dan Schedule Performance Index/SPI) dan untuk mengetahui perkiraan biaya dan waktu untuk penyelesaian proyek.

\section{TINJAUAN PUSTAKA}

\subsection{Earned Value Method (EVM)}

Menurut Santosa (2008), penggunaan konsep earned value dimulai pada akhir abad
20 di industri manufaktur. Tinjauan EVM dimasukkan dalam PMBOK Guide First Edition pada tahun 1987 dan edisi-edisi berikutnya. EVM mencapai momentumnya pada tahun 2000, ketika beberapa Negara bagian di Amerika Serikat mengharuskan penggunaan EVM pada semua proyek pemerintah. Flemming dan Koppelman (1994) menjelaskan konsep earned value dibandingkan manajemen biaya tradisional. Manajemen biaya tradisional hanya menyajikan dua dimensi saja yaitu hubungan yang sederhana antara biaya aktual dengan biaya rencana. Dengan manajemen biaya tradisional, status kinerja tidak dapat diketahui. Biaya aktual memang lebih rendah, namun kenyataan bahwa biaya aktual yang lebih rendah dari rencana ini tidak dapat menunjukkan bahwa kinerja yang telah dilakukan telah sesuai dengan target rencana. Sebaliknya, konsep earned value memberikan dimensi yang ketiga selain biaya aktual dan biaya rencana. Dimensi yang ketiga ini adalah besarnya pekerjaan secara fisik yang telah diselesaikan atau disebut earned value/percent complete.

\subsection{Konsep Cost Schedule Control System Criteria}

Menurut Ervianto (2004), indikator indikator yang dipakai dalam konsep nilai hasil yaitu:

1. BCWS atau budgeted cost of work scheduled

Merupakan anggaran biaya yang telah direncanakan berdasarkan jadwal pelaksanaan proyek. Untuk setiap periode yang diinginkan anggaran biaya pada jadwal pekerjaan dihitung pada level cost account dengan menjumlahkan seluruh anggaran paket pekerjaan.

2. BCWP atau budgeted cost for work performed

Anggaran biaya dari seluruh aktual pekerjaan yang sudah dilaksanakan sepanang periode konstruksi.

3. ACWP atau actual cost of work performed

Biaya actual yang dikeluarkan untuk penyelesaian pekerjaan pada periode waktu yang bersangkutan.

Beberapa istilah yang terkait dengan penilaian ini adalah: 
1. Cost Variance $(\mathrm{CV})=\mathrm{BCWP}-$ ACWP

2. Schedule Variance $(S V)=\mathrm{BCWP}-$ $\mathrm{BCW}$

3. Cost Performance Index (CPI) = BCWP / ACWP

4. Schedule Performance Index (SPI) = BCWP / BCWS

5. Budget Estimate to Complete $(\mathrm{BETC})=\frac{(B A C-B C W P)}{C P I}$

6. Budget Estimate at Complete (BEAC) $=\mathrm{ACWP}+\mathrm{BETC}$

(6)

7. Schedule Estimate to Complete $(\mathrm{SETC})=\frac{(S A C-(t B C W P-S V)}{S P I}$

8. Schedule Estimate at Completion $(\mathrm{SEAC})=\mathrm{tBCWP}+\mathrm{SETC}$ (8)

Atau

SPI) $) / \mathrm{SPI})$

$\mathrm{TE}=\mathrm{ATE}+((\mathrm{OD}-(\mathrm{ATE}) \mathrm{x}$ (9)

\section{METODE PENELITIAN}

Jenis penelitian yang digunakan adalah deskriptif kuantitatif, penelitian yang menggambarkan kondisi proyek tertentu dengan analisis data-data yang ada. Metode Earned Value akan digunakan untuk menganalisis pengendalian dengan menggabungkan aktivitas-aktivitas, rencana, definisi tugas, wewenang kerja, penganggaran, pelaporan, dan penjadwalan ke dalam satu sistem pengendalian manajemen. Penelitian dilakukan pada proyek pemeliharaan berkala jalan Provinsi Denpasar-Pesanggaran sepanjang $1,9 \mathrm{~km}$. Sumber data dan teknik pengumpulan data dalam penelitian ini disesuaikan dengan tujuan penelitian. Data primer diperoleh dengan survei di lapangan yaitu dengan melakukan wawancara terstruktur, dengan beberapa pihak yang terkait dalam pelaksanaan proyek antara lain dengan pelaksana dari kontraktor PT Aditya Sinar Pratama dan Konsultan Pengawas dari CV Veygasi Disain KSO CV Artha Pratama. Sedangkan data skunder yang didapat dari kontraktor dan konsultan pengawas antara
lain:Time Schedule, daftar harga bahan dan upah, daftar harga satuan pekerjaan, Rencana Anggaran Biaya dan laporan harian, mingguan dan bulanan proyek

Data-data yang telah dikumpulkan diolah dan dianalisis dengan tahapan sebagai sebagai berikut :

1. Analisis Cost Schedule Control System Criteria

Metode analisis dari sistem ini menggunakan 3 (tiga) parameter utama, agar dapat mengevaluasi setiap cost account dan level-level di atasnya dengan tepat. Parameter yang digunakan adalah BCWS, BCWP dan ACWP. Dari ketiga parameter tersebut dapat menunjukkan kemajuan dan kinerja pelaksanaan proyek seperti: Cost Variance (CV), Schedule Variance (SV), Cost Performance Index (CPI) dan Schedule Performance Index (SPI)

2. Analisis Varians

a. Cost Variance (CV)

b. Schedule Variance (SV)

3. Analisis Indeks Performansi

Kegiatan proyek tergantung pada efisiensi penggunaan sumber daya yang meliputi tenaga kerja, waktu dan biaya. Untuk mengetahui performa tersebut, ada dua perhitungan yang digunakan yaitu

a. Indeks Kinerja Jadwal atau Schedule Performance Index (SPI)

b. Indeks Kinerja Biaya atau Cost Performance Index (CPI)

4. Analisis Prakiraan Waktu dan Biaya Penyelesaian Akhir Proyek

Metode Earned Value juga berfungsi untuk memperkirakan biaya akhir proyek dan waktu penyelesaian proyek. Variabel yang digunakan untuk analisis ini adalah BETC, BEAC, BAC, BCWP , CPI dan SPI

5. Kesimpulan

Kesimpulan yang didapat dari hasil analisis menjelaskan rumusan masalah dan tujuan penelitian yang telah ditetapkan sebelumnya yaitu untuk mengetahui anggaran biaya dari seluruh aktual pekerjaan yang sudah dilaksanakan (Budgeted Cost for Work Performance), dan biaya aktual yang 
dikeluarkan untuk penyelesaian pekerjaan pada periode waktu yang bersangkutan (Actual Cost of Work Performance), untuk mengetahui varian biaya dan jadwal (Cost Variance dan Schedule Variance) dan untuk mengetahui kinerja proyek konstruksi dan prakiraan waktu dan biaya penyelesaian akhir proyek, dengan mengaplikasikan CPI (Cost Performance Index) dan SPI (Schedule Performance Index).

\section{HASIL PENELITIAN DAN PEMBAHASAN \\ 4.1 Budgeted Cost for Work Schedule ( BCWS \\ Anggaran biaya yang telah direncanakan} berdasarkan jadwal pelaksanaan proyek setelah ada pekerjaan tambah/kurang maka anggaran biaya proyek yang semula ditetapkan Rp 16.169.998.000,00 menjadi Rp 16.157.678.340,76. Berdasarkan data kontraktor dijelaskan bahwa perubahanperubahan yang terjadi setelah proyek berjalan, yaitu adanya pekerjaan tambah kurang, yaitu perubahan volume. Perubahan-perubahan volume item pekerjaan berpengaruh terhadap bobot pekerjaan.Untuk penelitian ini peninjauan dilakukan 20 (duapuluh) minggu prestasi proyek sampai tanggal 30 juli 2017. Jumlah bobot rencana perminggu yang diperoleh berdasarkan time schedule dari data kontraktor. Pada minggu pertama sampai minggu keempat rencana pekerjaan-pekerjaan yang dilakukan hanya mobilisasi dan pekerjaan pemeliharaan rutin. Sedangkan minggu kelima sampai minggu keempatbelas rencana item pekerjaan yang dikerjakan mulai bertambah sehingga bobot yang direncanakan juga bertambah. Pada minggu kelimabelas dan enambelas bertepatan dengan Hari Raya Idul Fitri, proyek diliburkan maka bobot rencana hanya $0,006 \%$. Sedangkan minggu ketujuhbelas sampai minggu duapuluh bobot yang direncanakan bertambah. Bobot pekerjaan yang direncanakan sampai minggu keduapuluh adalah sebesar $65,477 \%$. Perhitungan pajak dihitung pada minggu keduapuluh sebesar 10\% dari nilai proyek yaitu $10 \% \quad \mathrm{x} \quad \mathrm{Rp}$ 16.157.678.340,76 menjadi Rp 1.189.867.590,69. Nilai BCWS dihitung berdasarkan bobot rencana perminggu dikalikan dengan nilai proyek. Kemudian dihitung BCWS kumulatifnya dengan menjumlahkan antara BCWS tiap minggu.

\subsection{ACWP ( Actual Cost of Work Performance)}

Biaya aktual yang dikeluarkan untuk penyelesaian pekerjaan pada periode waktu tertentu yaitu dari minggu pertama sampai minggu duapuluh. Anggaran biaya aktual dihitung berdasarkan biaya langsung dan biaya tak langsung (Overhead). Biaya langsung proyek antara lain biaya tenaga, biaya bahan/material dan biaya peralatan. Sedangkan biaya tak langsung proyek adalah $10 \%$ dari biaya tenaga. Biaya-biaya proyek aktual dihitung berdasarkan laporan harian kontraktor. Biaya tenaga terdiri dari site manajer, pengawas proyek, pelaksana, administrasi teknik dan keuangan proyek, logistik, surveyor, operator, mekanik, sopir, pekerja, tukang dan mandor. Biaya bahan/material proyek terdiri dari pasir, batu kali, agregat kasar, agregat halus, paving block, semen, baja tulangan, kawat beton, kerb pracetak jenis 2, kerb pracetak jenis 3, frame, cover, tegel/ubin, paku, kayu perancah, udith 30x30 tangkapan air, aspal, aspal minyak, pasir beton. Sedangkan biaya sewa peralatan per jam terdiri dari concrete mixer, dump truck, water tanker, tamper, flat bed truck, crane 10:15 ton, wheel loader, genset, pedestrian roller, dan $A M P$.

Berdasarkan jumlah biaya langsung dan biaya tak langsung 10\% dari biaya tenaga, maka dapat dihitung nilai ACWP sedangkan untuk pajak dijumlahkan pada minggu keduapuluh. Setelah dijumlahkan kemudian ACWP kumulatif dihitung berdasarkan ACWP antara minggu pertama dengan kedua dan seterusnya. Contoh perhitungan ACWP diambil minggu X (Sepuluh). Pada minggu kesepuluh mulai tanggal 15 Mei 2017 sampai dengan 21 Mei 2017. Item pekerjaan yang dilaksanakan berdasarkan data lapangan adalah mobilisasi, pekerjaan drainase, pekerjaan struktur, pengembalian kondisi dan pekerjaan minor serta pekerjaan pemeliharaan rutin. Berdasarkan laporan harian dan mingguan proyek maka didapat biaya-biaya kebutuhan tenaga, kebutuhan bahan dan kebutuhan alat yang disebut biaya langsung proyek.

1. Biaya kebutuhan tenaga

Tanggal 15 Mei 2017 tenaga yang dibutuhkan adalah :

a. Site Manajer $1 \times$ Rp $150.000,00=$ Rp 150.000,00 
b. Pengawas Mutu $1 \quad \mathrm{x} \quad \mathrm{Rp}$ $125.000,00=\operatorname{Rp} 150.000,00$

c. Pelaksana 1 x Rp 110.000,00= Rp 110.000,00

d. Administrasi Teknik dan Keuangan 2 x Rp 100.000,00= Rp 200.000,00

e. Logistik $1 \times \mathrm{Rp} 100.000,00=\mathrm{Rp}$ $100.000,00$

f. Surveyor $1 \times$ Rp $110.000,00=R p$ $110.000,00$

g. Operator $2 \times \operatorname{Rp} 100.000,00=\mathrm{Rp}$ 200.000,00

h. Mekanik 3 x Rp 100.000,00 = Rp $300.000,00$

i. Sopir 1 x $\mathrm{Rp} 90.000,00=\mathrm{Rp}$ 90.000,00

j. $\quad$ Pekerja $85 \times \mathrm{Rp} 85.000,00=\mathrm{Rp}$ 7.225.000,00

k. Tukang $44 \times$ Rp $90.000,00=R p$ 3.960.000,00

1. Mandor $15 \times \mathrm{Rp} 100.000,00=\mathrm{Rp}$ 1.500.000,00

Sehingga total biaya tenaga yang dibutuhkan pada tanggal $15 \mathrm{Mei}$ 2017 adalah Rp 14.070.000,00.

Biaya kebutuhan bahan

Bahan-bahan yang diperlukan pada pekerjaan tanggal 15 Mei 2017 adalah

a. Batu kali 1,04 m3 x Rp $317,700,00=\operatorname{Rp} 330.408,00$

b. Semen $1591,89 \mathrm{~kg} \times \mathrm{Rp} 1.425,00$ $=2.268 .443,25$

c. Pasir 4,38 m3 x Rp 235.000,00= Rp 1.029.300,00

d. Frame 2 unit $\times$ Rp $633.360,00=$ Rp 1.266.720,00

e. Cover 2 unit $x$ Rp 435.625,00= Rp 873.250,00

f. Agregat kasar $2,72 \mathrm{~m} 3 \quad \mathrm{x} \quad \mathrm{Rp}$ $348.416,00=\operatorname{Rp} 947.691,52$

g. Kayu perancah $0,15 \mathrm{~m} 3$ x Rp $750.000,00=\operatorname{Rp} 112.500,00$

h. Paku 0,15 kg x Rp 15.500,00= Rp 2.325,00

i. Kerb pracetak jenis $2=62$ bh $\mathrm{x}$ $54.000,00=3.348 .000,00$

j. Kerb pracetak jenis $3=43$ bh $\mathrm{x}$ $66.000,00=2.838 .000,00$

k. Paving block $24,26 \mathrm{~m} 2 \mathrm{x}$ $110.000,00=2.668 .600,00$

Jadi total biaya bahan pada pekerjaan tersebut pada tanggal 15 Mei 2017 adalah Rp 15.685.237,77.
Biaya kebutuhan alat

Alat-alat yang digunakan pada pekerjaan tersebut adalah sewa per jam. Dalam satu hari dihitung 8 jam. Rincian dari pekerjaan yang dikerjakan pada tanggal 15 Mei 2017 adalah

a. Concrete Mixer $=1$ unit $\mathrm{x} 8$ jam $\mathrm{x}$ Rp 74.027,00 = Rp 592.216,00

b. Water Tanker $=1$ unit $\mathrm{x} 8$ jam $\mathrm{x}$ Rp 264.377,00 = Rp 2.115.016,00

c. Flat Bed Truck $=1$ unit $\mathrm{x} 8$ jam $\mathrm{x}$ Rp 440.968,57 = Rp 3.527.748,56

d. Tamper $=1$ unit $\times 8$ jam $\times \mathrm{Rp}$ $40.883,00=\operatorname{Rp} 327.064,00$

e. Crane $10-15$ ton $=1$ unit $\mathrm{x} 8$ jam $\mathrm{x} \quad \mathrm{Rp} 851.814,37=\mathrm{Rp}$ $6.814 .514,96$

f. Alat bantu $=.8$ jam x Rp $1.000,00$ $=\operatorname{Rp} 8.000,00$

Jadi total kebutuhan alat pada pekerjaan tersebut adalah Rp 13.384.559,00.

Biaya langsung proyek pada minggu $X=R p$ 96.335.000,00 + Rp 142.600.708,71 + Rp $156.643 .676,32=\operatorname{Rp} 395,579,385.03$

Biaya tak langsung diambil $10 \%$ dari biaya tenaga. Total biaya tak langsung pada minggu $\mathrm{X}$ adalah $10 \% \quad \mathrm{x} \quad \mathrm{Rp} 96.335 .000,00=$ 9.633.500,00.

Nilai ACWP pada minggu $X$ adalah jumlah biaya langsung dengan biaya tak langsung $=\mathrm{Rp}$ 395,579,385.03+ Rp 9.633.500,00 = Rp 405,212,885.03. Sedangkan nilai ACWP kumulatif sampai minggu ke sepuluh adalah Rp $3,449,270,946.34$.

\subsection{BCWP (Budgeted Cost for Work Performance)}

BCWP adalah anggaran biaya dari seluruh aktual pekerjaan yang sudah dilaksanakan sepanjang periode konstruksi. Berdasarkan data lapangan, data laporan harian dan laporan mingguan dari kontraktor maka bobot aktual dari proyek tersebut dapat dihitung. Hasil perhitungan BCWP bahwa kemajuan proyek sampai minggu keduapuluh adalah 75,68\%. Sedangkan kemajuan proyek yang direncanakan sampai minggu keduapuluh adalah $65,477 \%$. Dari nilai BCWP dengan BCWS terjadi selisih bobot pekerjaan antara aktual dengan rencana sebesar 10,203\%. Hal ini berarti proyek mengalami kemajuan sampai minggu keduapuluh. Kurva dan grafik BCWS, ACWP dab BCWP dapat dilihat pada gambar 1 
'S' Curve Earned Value dan gambar 2 di bawah ini:
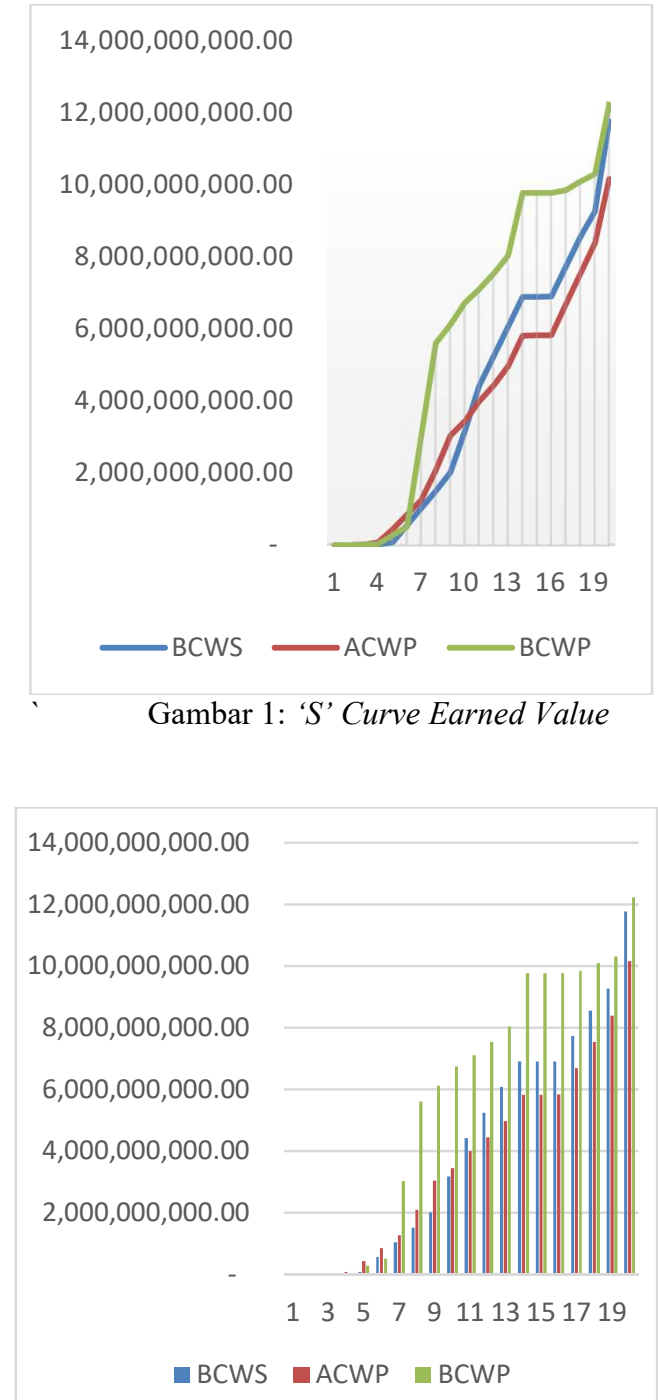

Gambar 2: Grafik Histogram BCWS, ACWP dan BCWP

Berdasarkan gambar 1 dan 2 dijelaskan bahwa perbandingan antara BCWP dengan BCWS adalah BCWP pada minggu keempat sampai minggu keduapuluh selalu berada di atas BCWS, hal ini berarti bahwa banyak kegiatan menurut jadwal/schedule yang seharusnya belum dikerjakan tetapi sudah dikerjakan terlebih dahulu. Perbandingan antara BCWS dengan ACWP dari minggu pertama sampai minggu kesepuluh ACWP selalu berada di atas BCWS, berarti pada minggu-minggu tersebut biaya aktual proyek yang dikeluarkan lebih besar dari biaya yang direncanakan. Sedangkan dari minggu kesebelas sampai keduapuluh biaya aktual yang dikeluarkan lebih kecil dari biaya yang direncanakan semula. Perbandingan antara BCWP dengan ACWP pada minggu pertama sampai keenam nilai BCWP selalu dibawah dari nilai ACWP berarti biaya aktual yang dikeluarkan pada proyek tersebut lebih besar dari biaya yang seharusnya dikeluarkan. Hal ini berarti pada minggu tersebut mengalami kerugian dari segi waktu dan biaya. Pekerjaan-pekerjaan yang dikerjakan pada minggu-minggu tersebut banyak mengalami hambatan, seperti adanya pohonpohon besar yang menghalangi pekerjaan trotoar, adanya pekerjaan lain di luar proyek seperti proyek PDAM dan DSDP, yang mempengaruhi pekerjaan pengaspalan dan pekerjaan trotoar. Sedangkan pada minggu ketujuh sampai keduapuluh ACWP berada di bawah BCWP, berarti biaya aktual yang dikeluarkan pada proyek tersebut lebih kecil dari biaya yang seharusnya dikeluarkan dalam kontrak. Biaya yang dikeluarkan lebih kecil dari biaya yang seharusnya dikeluarkan berarti proyek tersebut berjalan baik dan mendapat keuntungan. Jadi perjalanan proyek, berdasarkan kurva dan grafik histogram tersebut menjelaskan bahwa pada awal proyek mengalami kerugian, tetapi pada pertengahan sudah dapat menunjukkan kemajuan proyek yang signifikan sehingga pada pelaksanaan proyek perbandingan antara biaya aktual yang dikeluarkan lebih kecil dibandingkan dengan biaya yang seharusnya dikeluarkan. Demikian juga biaya aktual yang dikeluarkan lebih kecil dibandingkan dengan biaya yang direncanakan. Sehingga pada proyek tersebut sampai minggu keduapuluh sudah menunjukkan perjalanan proyek yang baik sesuai dengan yang diharapkan.

\subsection{Analisis Varian}

Analisis varian terdiri dari perhitungan Cost Variance (CV) dan Schedule Variance (SV). CV merupakan selisih antara nilai yang diperoleh setelah menyelesaikan paket-paket pekerjaan dengan biaya aktual yang terjadi selama pelaksanaan proyek.

Contoh perhitungan nilai $\mathrm{CV}$ digunakan minggu kesepuluh:

$$
\begin{aligned}
& \mathrm{BCWP}=\operatorname{Rp} 6,733,389,294.94 \\
& \text { ACWP }=\text { Rp 3,449,270,946.34 } \\
& \mathrm{CV}=\mathrm{BCWP}-\mathrm{ACWP}
\end{aligned}
$$




$$
\begin{aligned}
& =\operatorname{Rp~} 6,733,389,294.94-\mathrm{Rp} \\
& 3,449,270,946.34 \\
& =\text { Rp 3,231,232,,711.10 }
\end{aligned}
$$

Berdasarkan hasil perhitungan $\mathrm{CV}$ minggu kesepuluh menunjukkan nilai positif. Cost variance positif menunjukkan bahwa nilai paket-paket pekerjaan yang diperoleh lebih besar dibandingkan dengan biaya yang dikeluarkan untuk mengerjakan paket-paket pekerjaan tersebut, sebaliknya nilai negatif menunjukkan bahwa nilai paket-paket pekerjaan yang diselesaikan lebih rendah dibandingkan dengan biaya yang sudah dikeluarkan. Pada minggu kedua, ketiga, keempat, kelima, keenam dan keduapuluh menghasilkan Cost Variance negatif. Sedangkan minggu pertama, ketujuh, kedelapan, kesembilan, kesepuluh, kesebelas, keduabelas, ketigabelas, keempatbelas, kelimabelas, keenambelas, ketujuhbelas, kedelapanbelas dan kesebilanbelas menghasilkan Cost Variance positif. SV digunakan untuk menghitung penyimpangan antara BCWS dengan BCWP.

Contoh perhitungan nilai $\mathrm{CV}$ digunakan minggu kesepuluh:

$$
\begin{aligned}
& \mathrm{BCWP}=\operatorname{Rp} 6,733,389,294.94 \\
& \mathrm{BCWS}=\mathrm{Rp} 3,174,660,640.39 \\
& \mathrm{SV}=\mathrm{BCWP}-\mathrm{BCWS} \\
& =\mathrm{Rp} 6,733,389,294.94-\mathrm{Rp} \\
& =\operatorname{Rp} 3,558,728,654.55
\end{aligned}
$$$$
3,174,660,640.39
$$

Nilai positif menunjukkan bahwa paketpaket pekerjaan proyek yang terlaksana lebih banyak dibanding rencana. Sebaliknya nilai negatif menunjukkan kinerja pekerjaan yang buruk karena paket-paket pekerjaan yang terlaksana lebih sedikit dari jadwal yang direncanakan. SV negatif terdapat pada minggu pertama, kedua, ketiga, keenam dan keduapuluh. Pada minggu pertama menghasilkan $\mathrm{CV}$ positif dan SV negatif, hal ini berarti pada minggu pertama dari segi biaya yang dikeluarkan lebih kecil dari yang dianggarkan dengan jadwal pelaksanaan pekerjaan lebih lambat dari yang direncanakan. Pada minggu kedua, ketiga dan keenam menghasilkan CV negatif dan SV negatif, hal ini berarti pada minggu kedua, ketiga dan keenam dari segi biaya yang dikeluarkan lebih besar dari yang dianggarkan dengan jadwal pelaksanaan pekerjaan lebih lambat dari yang direncanakan. Pada minggu keempat dan kelima menghasilkan CV negatif dan SV postif, hal ini berarti pada minggu keempat dan kelima dari segi biaya yang dikeluarkan lebih besar dari yang dianggarkan dengan jadwal pelaksanaan pekerjaan lebih cepat dari yang direncanakan. Pada minggu keenam, kinerja proyek menghasilkan $\mathrm{CV}$ negatif dan SV positif, berarti kinerja proyek pada minggu keenam pekerjaan selesai lebih cepat dari pada anggaran dengan biaya lebih tinggi dari anggaran. Pada minggu ketujuh sampai dengan minggu keduapuluh menghasilkan $\mathrm{CV}$ positif dan SV positif, berarti dari segi biaya yang dikeluarkan lebih kecil dari yang dianggarkan dengan jadwal pelaksanaan pekerjaan lebih cepat dari yang direncanakan. Berdasarkan hasil analisis data dengan menggunakan metode Earned Value pada Proyek Pemeliharaan Berkala Jalan Provinsi Denpasar-Pesanggaran, menunjukkan penggunaan metode tersebut sangat penting dilaksanakan dalam pengendalian proyek terutama pengendalian biaya dan waktu. Pengendalian biaya dan waktu bertujuan untuk mengendalikan proyek supaya tujuan proyek dapat tercapai yaitu kesesuaian antara perencanaan dengan pelaksanaan. Hasil analisis menunjukkan kondisi proyek dapat

\begin{tabular}{|c|c|c|c|}
\hline MINGGU & SV & $\mathrm{CV}$ & Arti \\
\hline I & Negatif & Positif & $\begin{array}{l}\text { Dari segi } \\
\text { jadwal } \\
\text { pelaksanaan } \\
\text { pekerjaan } \\
\text { lebih lambat } \\
\text { dari yang } \\
\text { direncanakan } \\
\text { dengan biaya } \\
\text { yang } \\
\text { dihabiskan } \\
\text { lebih kecil } \\
\text { dari yang } \\
\text { dianggarkan }\end{array}$ \\
\hline $\begin{array}{l}\text { II,III\&V } \\
\text { I }\end{array}$ & Negatif & Negatif & $\begin{array}{l}\text { Dari segi } \\
\text { jadwal } \\
\text { pelaksanaan } \\
\text { pekerjaan } \\
\text { lebih lambat } \\
\text { dari yang } \\
\text { direncanakan } \\
\text { dengan biaya }\end{array}$ \\
\hline
\end{tabular}
diketahui tiap hari, tiap minggu, tiap bulan sampai proyek selesai. Untuk memudahkan melihat kondisi proyek berdasarkan harga varian biaya dan varian jadwal serta artinya maka dapat dilihat pada tabel 2 di bawah ini:

Tabel 1 : Harga Varian Biaya dan Varian Jadwal 


\begin{tabular}{|c|c|c|c|}
\hline MINGGU & SV & $\mathrm{CV}$ & Arti \\
\hline & & & $\begin{array}{l}\text { yang } \\
\text { dihabiskan } \\
\text { lebih besar } \\
\text { dari yang } \\
\text { dianggarkan }\end{array}$ \\
\hline IV\&V & Positif & Negatif & $\begin{array}{l}\text { Dari segi } \\
\text { jadwal } \\
\text { pelaksanaan } \\
\text { pekerjaan } \\
\text { lebih cepat } \\
\text { dari yang } \\
\text { direncanakan } \\
\text { dengan biaya } \\
\text { yang } \\
\text { dihabiskan } \\
\text { lebih besar } \\
\text { dari yang } \\
\text { dianggarkan }\end{array}$ \\
\hline VII-XX & Positif & Positif & $\begin{array}{l}\text { Dari segi } \\
\text { jadwal } \\
\text { pelaksanaan } \\
\text { pekerjaan } \\
\text { lebih cepat } \\
\text { dari yang } \\
\text { direncanakan } \\
\text { dengan biaya } \\
\text { yang } \\
\text { dihabiskan } \\
\text { lebih kecil } \\
\text { dari yang } \\
\text { dianggarkan }\end{array}$ \\
\hline
\end{tabular}

\subsection{Analisis Indeks Performansi}

Kegiatan proyek tergantung pada efisiensi penggunaan sumber daya yang meliputi tenaga kerja, waktu dan biaya. Untuk mengetahui performa tersebut, ada dua perhitungan yang digunakan yaitu Indeks Kinerja Jadwal atau Schedule Performance Index (SPI) dan Indeks Kinerja Biaya atau Cost Performance Index (CPI)

SPI dapat dihitung dengan membandingkan nilai BCWP dengan BCWS. Contoh perhitungan digunakan minggu kesepuluh:

$$
\begin{aligned}
& \mathrm{BCWP}=\operatorname{Rp~6,733,389,294.94} \\
& \mathrm{BCWS}=\mathrm{Rp} 3,174,660,640.39 \\
& \mathrm{SPI}=\mathrm{BCWP} / \mathrm{BCWS}=2,121>1
\end{aligned}
$$

(Hal ini berarti bahwa pada minggu kesepuluh proyek berjalan lebih cepat).

CPI dapat dihitung dengan membandingkan nilai BCWP dengan ACWP. Contoh perhitungan digunakan minggu kesepuluh:

$\mathrm{BCWP}=\operatorname{Rp} 6,733,389,294.94$

$\mathrm{ACWP}=\operatorname{Rp} 3,502,156,583.84$
CPI $=\mathrm{BCWP} / \mathrm{ACWP}=1,9226>$ 1 (Hal ini berarti bahwa pada minggu kesepuluh biaya lebih kecil dari yang dianggarkan).

Berdasarkan tabel 3 dijelaskan bahwa pada minggu pertama nilai SPI lebih kecil dari 1 dan CPI mempunyai nilai lebih besar dari satu, berarti pekerjaan lebih lambat dari jadwal dengan biaya yang lebih kecil dari yang dianggarkan. Pada minggu kedua, ketiga dan keenam nilai SPI dan CPI lebih kecil dari 1 , berarti terjadi keterlambatan dan pembengkakan biaya. Minggu keempat dan kelima nilai SPI lebih besar dari 1 dan CPI lebih kecil dari 1, berarti pekerjaan lebih cepat dari jadwal dengan biaya yang lebih besar dari yang dianggarkan. Sedangkan pada minggu ketujuh sampai dengan duapuluh nilai SPI dan CPI masing-masing lebih besar dari 1 bahwa pekerjaan lebih cepat dari jadwal dengan biaya yang lebih kecil dari yang dianggarkan. Hasil analisis indeks kinerja jadwal dan indeks kinerja biaya pada Proyek Pemeliharaan Berkala Jalan Provinsi Denpasar-Pesanggaran dapat digunakan untuk menilai atau evaluasi dari berbagai pihak yang terlibat dalam proyek konstruksi. Hal yang sangat sensitif dalam proyek konstruksi jika berkaitan dengan masalah sumberdaya berupa uang, sehingga kelancaran pembayaran kepada kontraktor harus terjamin. Lancar dan tidaknya arus uang dalam proyek konstruksi tergantung dari berbagai unsur pengelola proyek misalnya kontraktor, owner, dan pengawas lapangan. Manajer proyek yang ingin mengetahui status proyek pada saat tertentu bisa melihat nilai-

\begin{tabular}{|c|c|c|c|}
\hline Minggu & SPI & CPI & Arti \\
\hline I & $<1$ & $>1$ & $\begin{array}{l}\text { Kinerja } \\
\text { proyek } \\
\text { lebih } \\
\text { lambat dari } \\
\text { jadwal } \\
\text { rencana } \\
\text { dan biaya } \\
\text { aktual yang } \\
\text { dikeluarkan } \\
\text { lebih kecil } \\
\text { dari nilai } \\
\text { pekerjaan } \\
\text { yang } \\
\text { didapat }\end{array}$ \\
\hline II,III,VI & $<1$ & $<1$ & Kinerja \\
\hline
\end{tabular}
nilai besaran CPI dan SPI.

Tabel 2 : SPI dan CPI 


\begin{tabular}{|c|c|c|c|}
\hline Minggu & SPI & CPI & Arti \\
\hline & & & $\begin{array}{l}\text { proyek } \\
\text { lebih } \\
\text { lambat dari } \\
\text { jadwal } \\
\text { rencana } \\
\text { dan biaya } \\
\text { aktual yang } \\
\text { dikeluarkan } \\
\text { lebih besar } \\
\text { dari nilai } \\
\text { pekerjaan } \\
\text { yang } \\
\text { didapat }\end{array}$ \\
\hline IV-V & $>1$ & $<1$ & $\begin{array}{l}\text { Kinerja } \\
\text { proyek } \\
\text { lebih cepat } \\
\text { dari jadwal } \\
\text { rencana } \\
\text { dan biaya } \\
\text { aktual yang } \\
\text { dikeluarkan } \\
\text { lebih besar } \\
\text { dari nilai } \\
\text { pekerjaan } \\
\text { yang } \\
\text { didapat }\end{array}$ \\
\hline VII-XX & $>1$ & $>1$ & $\begin{array}{l}\text { Kinerja } \\
\text { proyek } \\
\text { lebih cepat } \\
\text { dari jadwal } \\
\text { rencana } \\
\text { dan biaya } \\
\text { aktual yang } \\
\text { dikeluarkan } \\
\text { lebih kecil } \\
\text { dari nilai } \\
\text { pekerjaan } \\
\text { yang } \\
\text { didapat }\end{array}$ \\
\hline
\end{tabular}

\subsection{Analisis Perkiraan Biaya dan Waktu untuk Menyelesaikan Proyek}

Biaya dan waktu penyelesaian proyek sesuai dengan kontrak adalah $\mathrm{Rp}$ 16,157,678,340.76. Pada penelitian ini ditinjau sampai minggu keduapuluh, maka untuk menganalisis perkiraan biaya untuk menyelesaikan proyek dianalisis berdasarkan minggu keduapuluh. Bila dianggap kinerja biaya pada pekerjaan tersisa adalah tetap, maka BETC adalah merupakan perkiraan biaya yang diperlukan untuk menyelesaikan pekerjaan tersisa, sehingga BETC adalah anggaran pekerjaan tersisa dibagi dengan indeks kinerja biaya. Parameter-parameter yang digunakan untuk menghitung BETC adalah BAC, BCWP dan CPI.

$$
\begin{aligned}
& \mathrm{BETC}=(\mathrm{BAC}-\mathrm{BCWP}) / \mathrm{CPI} \\
& =(\operatorname{Rp~16,157,678,340.76} \text {. }
\end{aligned}
$$

$$
=\operatorname{Rp~3,285,414,629.35~}
$$

Jumlah pengeluaran sampai pada saat pelaporan ditambah perkiraan biaya untuk pekerjaan tersisa. Perkiraan biaya total diperlukan untuk mengetahui apakah dana yang tersisa cukup untuk menyelesaikan pekerjaan yang tersisa. Parameter-parameter yang digunakan untuk menghitung BEAC adalah ACWP dan BETC.

$$
\begin{aligned}
& \mathrm{BEAC}=\mathrm{ACWP}+\mathrm{BETC} \\
& =\operatorname{Rp} 10,223,691,576.86+\mathrm{Rp} \\
& 3,285,414,629.35 \\
& =\operatorname{Rp} 13,450,932,004.96<
\end{aligned}
$$

$\mathrm{BAC}=\mathrm{Rp} 16,157,678,340.76$

Jadi dapat disimpulkan bahwa Proyek Pemeliharaan Berkala Jalan Provinsi DenpasarPesanggaran tidak mengalami kerugian.

Bila dianggap kinerja jadwal pada pekerjaan tersisa tetap, seperti pada saat pelaporan, maka SETC adalah waktu pekerjaan tersisa (6 minggu) dibagi indek kinerja jadwal (SPI = 1.039).

$$
\text { SETC }=6 / 1.039=5.77 \text { minggu }
$$

Menghitung Jumlah waktu pelaksanaan pekerjaan sampai pada saat pelaporan ditambah perkiraan waktu yang dibutuhkan untuk menyelesaikan pekerjaan tersisa. (SEAC). Parameter-parameter yang digunakan adalah $\mathrm{tBCWP}=20$ minggu dan $\mathrm{SETC}=5.77$ minggu .

$$
\text { SEAC } \quad=20+5.77=25.77 \text { minggu }<
$$
26 minggu

Jadi estimasi waktu penyelesaian proyek adalah 25.77 minggu. Hal ini berarti pada Proyek Pemeliharaan Berkala Jalan Provinsi Denpasar-Pesanggaran tidak mengalami keterlambatan, karena waktu penyelesaian proyek sesuai dengan time schedule yang direncanakan yaitu durasi rencana penyelesaian proyek 26 minggu.

\section{KESIMPULAN}

Hasil penelitian pengendalian proyek dengan Earned Value Method (EVM) pada Proyek Pemeliharaan Berkala Jalan Provinsi Denpasar-Pesanggaran memberikan kesimpulan bahwa:

1. Kinerja proyek pada minggu pertama menghasilkan CV positif, SV negatif, SPI $<1$ dan $\mathrm{CPI}>1$, berarti pekerjaan 
lebih lambat dari jadwal dengan biaya yang lebih kecil dari yang dianggarkan. Pada minggu kedua, ketiga dan keenam menghasilkan $\mathrm{CV}$ negatif, SV negatif, SPI $<1$ dan $\mathrm{CPI}<1$, berarti terjadi keterlambatan dan pembengkakan biaya. Pada minggu keempat dan kelima menghasilkan CV negatif, $\mathrm{SV}$ positif, $\mathrm{SPI}>1$ dan $\mathrm{CPI}<1$, berarti pekerjaan lebih cepat dari jadwal dengan biaya yang lebih besar dari yang dianggarkan. Pada minggu ketujuh sampai dengan minggu duapuluh menghasilkan $\mathrm{CV}$ positif, SV positif, SPI $>1$ dan $\mathrm{CPI}>1$, pekerjaan lebih cepat dari jadwal dengan biaya yang lebih kecil dari yang dianggarkan.

2. Perkiraan biaya total diperlukan untuk menyelesaikan pekerjaan adalah sebesar Rp 13,450,932,004.96 lebih kecil dibandingkan dengan biaya pada kontrak sebesar Rp 16,157,678,340.76. Perkiraan waktu penyelesaian proyek adalah 25.77 minggu lebih kecil dari durasi rencana penyelesaian 26 minggu.Hal ini proyek tersebut setelah dianalisis dengan Earned Value Method tidak mengalami kerugian dan tidak mengalami keterlambatan.

\section{DAFTAR PUSTAKA}

Ervianto I.W. (2004). "Teori Aplikasi Manajemen Proyek Konstruksi”. Yogyakarta: Penerbit Andi.

Heryanto.I. dan Triwibowo T. (2013). "Manajemen Proyek Berbasis Teknologi Informasi”. Penerbit Imformatika Bandung.

Juliana,2016, “Analisis Pengendalian Biaya dan Waktu pada Proyek Konstruksi dengan Metode Earned Value Management" Jurnal Faktor Exacta

Maromi.M.I dan Indryani R., 2015, "Metode Earned Value untuk Analisa Kinerja Biaya dan Waktu Pelaksanaan Condotel De Vasa Surabaya" Jurnal Teknik ITS.

Priyo.M. dan Wibowo.N.A, 2008, "Konsep Earned Value dalam Aplikasi Pengelolaan Proyek Konstruksi", Jurnal Ilmiah Semesta Teknik
Santosa B., 2008. "Manajemen Proyek Konsep dan Implementasinya”. Yogyakarta: Penerbit Graha Ilmu.

$\begin{array}{cr}\text { Simarmata.R.T dan } & \text { Mardiaman, } \\ \text { 2016,"Pengendalian } & \text { Biaya } \\ \text { Menggunakan Metode Nilai Hasil } \\ \text { Pelaksanaan Aroyek } & \text { (Kasus: } \\ \text { Pembangunan Pabrik Kelapa Sawit)", } \\ \text { Konferensi Nasional Teknik Sipil }\end{array}$
Konferensi Nasional Teknik Sipil 